\title{
Travel Anxiety, Risk Attitude and Travel Intentions towards "Travel Bubble" Destinations in Hong Kong: Effect of the Fear of COVID-19
}

\author{
Jian Ming Luo ${ }^{1}$ and Chi Fung Lam ${ }^{2, *}$ \\ 1 Faculty of International Tourism and Management, City University of Macau, Macau, China; \\ kenny.luo@connect.polyu.hk \\ 2 Department of Finance, The Chinese University of Hong Kong, Hong Kong, China \\ * Correspondence: kelvinlam@baf.cuhk.edu.hk
}

Received: 22 September 2020; Accepted: 6 October 2020; Published: 27 October 2020

\begin{abstract}
The impacts of COVID-19 are massive. Global tourism is one of the industries that is heavily affected. "Travel bubble", a recent term initiated by travel operators, is a programme that allows tourists to travel to countries nearby without quarantine requirements. This study investigates the relationship amongst fear of COVID-19, travel anxiety, risk attitude and travel intention towards "travel bubble" destinations. Results show that fear of COVID-19, travel anxiety and risk attitude negatively impact travel intention. Furthermore, travel anxiety and risk attitude moderate the indirect impacts between fear of COVID-19 and travel intention. Future research and implications of practices are presented.
\end{abstract}

Keywords: COVID-19; fear; travel anxiety; risk attitude; intention

\section{Introduction}

World tourism has decreased by more than 80 percent since the outbreak of COVID-19 in 2019. In the first quarter of 2020, tourist arrivals dropped by more than 20 percent [1]. The COVID-19 outbreak has not only caused many hospitality-related industries, such as restaurants, bars and hotels, to shut down; many countries also shut down their borders, thus halting domestic and international travel. Hong Kong is no exception. Ever since the outbreak of COVID-19, 65 international airlines have reduced their flights by 95 percent. From January to July 2020, tourist arrivals decreased by over 90 percent [2].

Travel bubbles, also known as "Travel Bridges" or "Corona Corridors", are considered a solution to the current pandemic, especially considering that the pandemic is expected to persist for a long time. The first "travel bubble" destination has been initiated by Estonia, Latvia and Lithuania. Citizens from these countries are allowed to travel freely (without quarantine requirements) within these countries [3]. Many Hong Kong tourism operators suggested the Hong Kong government to initiate this programme with countries or cities nearby where COVID-19 has been contained, such as Thailand, Japan, etc. $[4,5]$. However, Yetgin and Benligiray [6] argued that under this circumstance, economic and social pressures will cause many psychological and physiological diseases. This situation is worsened when people are surrounded by rumours and misleading false information about COVID-19 [7].

Previous research has shown that anxiety is a crucial determinant of behaviour [8]. For example, when people become more anxious about the virus, they tend to maintain a high level of personal hygiene, more social distancing and are more likely to get vaccinated when available [8]. In addition, they may overstock necessities, conduct unnecessary medical tests, or misinterpret their minor symptoms as signs of serious infection [9]. Anxiety is a mental state of tension and worry about the 
future [10] and high anxiety might act as a signal to avoid taking risks [11]. The outbreak of COVID-19 does not only make people anxious, but it also scares people. Therefore, understanding how this outbreak affects people's mental health is important [12,13].

Although the desire to travel is closely related to the affective state of an individual, tourism researchers generally pay little attention to research on people's feelings and emotions [14]. Some recent studies have explained how emotions can affect people's behaviour $[15,16]$. More evidence can be found in studies of behaviour intentions [17]. Hence, emotion can affect how people decide their destinations and their behaviour [18]. Fear is a basic emotion [18]. Hence, the fear of the pandemic recently would affect people's travel behaviour. COVID-19 does not only affect tourism but also the global economy. Researchers have studied the general effect of COVID-19 on tourism [19,20]. However, no studies have been conducted on travel behaviour, which includes the psychological effects of COVID-19. Therefore, the purpose of this study is to investigate the relationship between the fear of COVID-19, travel anxiety, attitude, and behaviour intention in "travel bubble" destinations.

\section{Literature Review and Hypothesis Development}

\subsection{Fear of COVID-19}

Emotion is hard to define because it is difficult to observe how emotion is developed, created and expressed [21]. The common consensus of the definition of emotion is that it is difficult to observe. Emotions involve a number of component processes encompassing subjective feelings, expressive motor behaviour, physiological arousal, cognitive appraisal and a behavioural tendency [22]. Many psychological emotion theorists agreed that emotion is not a simple phenomenon, and includes joy, acceptance, fear, surprise, sadness, anger, disgust and expectancy [23,24].

Since the outbreak, people have grown fearful of COVID-19. Fear, by general definition, is an emotion triggered by danger, pain or harm [25]. A viral outbreak, including COVID-19, could cause people to fear [26]. Researchers have studied fear and have developed many psychometric "fear scales" to measure the degree of "fear" of individuals. Recent studies, such as Ahorsu et al. [12], used these psychometric scales to measure the level of fear caused by COVID-19.

Regardless of the field of study, anxiety and fear are considered two different emotions [27]. Theoretically, fear is a primary emotion that is experienced by all human beings regardless of age, race and culture. Fear is an awareness of danger. Anxiety is the unpleasant feeling and physiological response when a person is scared [28]. COVID-19 has infected more than 10 million people worldwide; hence, people easily feel fear, panic and anxiety [12]. When there is a large amount of unverified, fake, or exaggerated information shared via social and online media, Rubin and Wessely [29] argued that such misinformation will increase the level of panic.

\subsection{Travel Anxiety}

Anxiety, loosely speaking, is an emotional response to stress, potential risks or actual risks. Gudykunst and Hammer [30] defined anxiety as fear of negative consequences. Dowling and Staelin [31] argued that when people buy something risky, the unknown consequence creates anxiety. McIntyre and Roggenbuck [32] extended this definition to include the feeling of being nervous, apprehensive, stressed, vulnerable, uncomfortable, disturbed, scared or panicked. Hullet and Witte [33] further included frustration and awkwardness in the definition.

Travelling to any destination involves risk and uncertainty; hence, people must evaluate a variety of factors, such as attributes of the products or destination, potential negative results, necessity and values. However, people have different evaluations of many products. For example, some people may consider one destination scary and dangerous, whereas others may regard the same destination as fun and exciting. Ahorsu et al. [12] found a positive relationship between the fear of COVID-19 and hospital anxiety. When people are constantly exposed to local and international news on fatalities 
and the infection rate of COVID-19, the degree of fear and anxiety increases. Hence, the level of life satisfaction decreases [34]. We formulate the following hypothesis.

Hypothesis 1 (H1). Fear of COVID-19 positively affects travel anxiety towards "travel bubble" destinations.

\subsection{Risk Attitudes}

Attitude is a stable and persistent psychological construct that can effectively affect and predict human behaviour [35]. Risk attitude, as the name suggests, is an attitude towards risk. It is a mindset on risk-taking behaviour under an uncertain or risky environment [36]. People usually act rationally under risk or uncertain circumstances. They may hedge or mitigate the risk entirely or partially [37]. Although complete avoidance of risk is sometimes possible, this option is less likely chosen [37]. Instead, people usually take measures, such as creating back-up plans or flexible plans according to the nature of the risk [38]. Risk perception or the perception of risk is important to consumers' decisions and judgement [39]. Risk perception is a complex perception formed by an individual on the basis of the impact of the negative consequence and the environment. Researchers argued that people tend to optimise their risk-taking behaviour by balancing the expected benefit and loss [40], whereas other researchers argued that people form their perception from individual experiences and environmental circumstances, such as media reports [41,42]. Recently, Xie, Huang, Li, \& Zhu [43] found that COVID-19 affects people's perception of and attitude towards food. Thus, we propose the following hypotheses.

Hypothesis 2 (H2). Fear of COVID-19 positively affects risk attitude towards "travel bubble" destinations.

Hypothesis 3 (H3). Travel anxiety positively affects risk attitude towards "travel bubble" destinations.

\subsection{Travel Intention}

Travel intention is defined as one's desire or intention to travel. Travel intention has two sources: personal and information source. In the process of forming perception, information sources are relatively important [44]. In addition to personal and information source, risk and safety are important factors that determine travel intention. Risk is associated with anxiety because of what may happen during a trip. For example, the possibility of terrorism in a destination will commonly form a perception of danger. This perception will result in a corresponding decision. Under such circumstances, people will tend to choose less risky destinations [45,46].

When a destination is viewed as "unsafe", people may form a negative perception [47]. This form of perception is developed via information sources, such as news from mainstream and social media [48]. For example, when mainstream media focuses on the number of infected people, the number of deaths, the number of stores that have closed and the businesses that have gone bankrupt due to COVID-19, people begin to worry about their jobs. People will grow anxious and their perceived level of safety in a destination decreases; hence, travel intention is reduced $[49,50]$. Therefore, we propose the following hypotheses.

Hypothesis 4 (H4). Travel anxiety negatively affects travel intention towards "travel bubble" destinations.

Hypothesis 5 (H5). Risk attitude negatively affects travel intention towards "travel bubble" destinations.

Hypothesis 6 (H6). Fear of COVID-19 negatively affects travel intention towards "travel bubble" destinations.

\section{Method}

This study uses measurement scales from existing research to develop the questionnaire. Previous studies have shown that these measurement scales are valid and significant. This study uses a 
5-point Likert scale, where 1 means "strongly disagree" and 5 means "strongly agree". SPSS (IBM Corp., Armonk, NY, USA) and AMOS 22.0 (IBM Corp., Armonk, NY, USA) are used to process the data and estimate the structural equations. The description of the scale is as follows:

Seven items measure Fear of COVID, and these items were developed by Ahorsu et al. [12] and Satici et al. [34]. A sample item is "I am afraid of losing my life because of COVID-19".

Six items measure Travel Anxiety, and these items were developed by Reisinger and Mavondo [49] and Wachyuni and Kusumaningrum [50]. A sample item is "I will panic when I travel during the COVID-19 pandemic".

Three items measure Risk Attitude, and these items were adopted from Zhu and Deng [46]. A sample item is "I will not eat with local friends and relatives after their trip to a travel bubble destination".

Three items measure Travel Intention, and these items were adopted from Reisinger and Mavondo [49] and Zhu and Deng [46]. A sample item is "I prefer to travel to 'travel bubble' destinations over other forms of tourism".

All items were back-translated in Chinese, and bilingual tourism scholars verified the accuracy of the translation. Moreover, marketing and tourism scholars checked the validity of the content. We further conducted a pilot test before the actual survey. Fifteen individuals were invited to participate in the pilot test. Changes were made on the basis of their opinions. In the final version, 19 items were included in the measurement scales. The remaining parts of the questionnaire collected the demographic information of participants.

The targets are Hong Kong residents with knowledge about "travel bubble" destinations. The screening questions in the questionnaire will assure the identity of the respondents. Since the data was collected during the pandemic when social distancing should be imposed, therefore, an online survey was the best option [51]. Since 06 July 2020, news from online and traditional media has reported that there are 8 to 10 countries to be included in the travel bubble arrangements [4]. This study adopts convenient sampling. Online questionnaire with a web link was sent via personal contacts in social media. The questionnaire was initially distributed to the researchers' personal network on WhatsApp and WeChat in Hong Kong. No incentive scheme was provided. Respondents could forward the survey to their friends and relatives in Hong Kong from July 6 to Aug 16, 2020. A total of 303 questionnaires were usable.

\section{Results}

\subsection{Respondent Profiles}

Gender distribution is roughly equal. Several respondents are single/divorced/widowed, have an undergraduate degree and aged 18 to 45 years old. Most of them are working and have a monthly income ranging from HKD 10,001 to 50,000 per month (see Table 1).

\subsection{Measurement Model}

SPSS20 and AMOS22 are used to perform confirmatory factor analysis (CFA). The results show the CFA is valid in terms of reliability, convergent validity and discriminant validity. Table 2 shows that the Cronbach's alphas of all coefficients are between 0.904 and 0.919 . This result satisfies the minimum requirement [52]. The result of convergent validity is also satisfactory. All factor loadings are significantly different from zero, ranging from 0.631 to 0.928 . The composite reliability of each construct is higher than 0.5. According to Fornell and Larcker [53], discriminant validity can be examined by the difference of the average variance and the squared root correlation (see Table 3 ). The measurement model is valid, that is, the standardised chi-squared is 2.348, Comparative Fit Index (CFI) is 0.954, Tucker-Lewis Index (TLI) is 0.946, Goodness of Fit Index (GFI) is 0.886 and the acceptable range of root-mean-square error of approximation(RMSEA) is 0.067 . These numbers indicate that the model is acceptable [54]. 
Table 1. The Demographic Profile of Participants.

\begin{tabular}{cccc}
\hline Variable & & Frequency $(n=303)$ & $\%$ \\
\hline \multirow{2}{*}{ Gender } & Male & 165 & 54.5 \\
& Female & 138 & 45.5 \\
\hline \multirow{2}{*}{ Marital Status } & Married & 129 & 42.6 \\
& Single/Divorced/Widowed & 174 & 57.4 \\
\hline \multirow{4}{*}{ Age } & $18-25$ & 86 & 28.4 \\
& $26-35$ & 59 & 19.5 \\
& $36-45$ & 68 & 22.4 \\
& $46-55$ & 61 & 20.1 \\
Education & 55 or above & 29 & 9.6 \\
\hline \multirow{5}{*}{ Occupation } & High school or below & 43 & 14.2 \\
& Diploma & 63 & 20.8 \\
& Undergraduates & 124 & 40.9 \\
& Graduates or above & 73 & 24.1 \\
\hline & Working & 208 & 68.6 \\
& Student & 50 & 16.5 \\
& Housewife & 17 & 5.6 \\
& Retired & 23 & 7.6 \\
& Others & 5 & 1.7 \\
\hline
\end{tabular}

Table 2. Results of Confirmatory Factor Analysis.

\begin{tabular}{|c|c|c|c|c|c|}
\hline $\begin{array}{c}\text { Latent } \\
\text { Variable }\end{array}$ & Measured Item & $\begin{array}{l}\text { Standardized } \\
\text { Loading }\end{array}$ & $\begin{array}{l}\text { Cronbach's } \\
\text { Alpha }\end{array}$ & $\begin{array}{l}\text { Component } \\
\text { Reliability } \\
\text { (CR) }\end{array}$ & $\begin{array}{c}\text { Average } \\
\text { Variance } \\
\text { Extracted } \\
\text { (AVE) }\end{array}$ \\
\hline \multirow{7}{*}{$\begin{array}{l}\text { Fear of } \\
\text { COVID-19 }\end{array}$} & 1. I am most afraid of the novel coronavirus & 0.794 & 0.904 & 0.906 & 0.582 \\
\hline & $\begin{array}{l}\text { 2. It makes me uncomfortable to think about } \\
\text { novel coronavirus }\end{array}$ & 0.732 & & & \\
\hline & $\begin{array}{l}\text { 3. My hands become sweaty when I think } \\
\text { about COVID-19 }\end{array}$ & 0.787 & & & \\
\hline & 4. I am afraid of losing my life because of COVID-19 & 0.798 & & & \\
\hline & $\begin{array}{l}\text { 5. When watching news and stories about novel } \\
\text { coronavirus on social media or any other media } \\
\text { (i.e., TV, Radio), I become nervous or anxious }\end{array}$ & 0.631 & & & \\
\hline & $\begin{array}{l}\text { 6. I cannot sleep because I am worried about getting } \\
\text { the novel coronavirus }\end{array}$ & 0.81 & & & \\
\hline & $\begin{array}{l}\text { 7. My heart races or palpitates when I think about } \\
\text { getting COVID-19 }\end{array}$ & 0.771 & & & \\
\hline \multirow{6}{*}{ Travel Anxiety } & $\begin{array}{l}\text { 8. I feel uncomfortable after thinking of going on a } \\
\text { tour during a pandemic }\end{array}$ & 0.794 & 0.919 & 0.920 & 0.656 \\
\hline & $\begin{array}{l}\text { 9. I feel that my body is not fit after planning } \\
\text { tourism activities during the pandemic }\end{array}$ & 0.838 & & & \\
\hline & 10. I was afraid to go on a tour during the pandemic & 0.82 & & & \\
\hline & $\begin{array}{l}\text { 11. I will panic when I travel during the COVID-19 } \\
\text { 12. I sweat after deciding to travel during }\end{array}$ & 0.823 & & & \\
\hline & a pandemic & 0.78 & & & \\
\hline & $\begin{array}{l}\text { 13. I feel an irregular heartbeat when I think of going } \\
\text { on a tour during the pandemic }\end{array}$ & 0.803 & & & \\
\hline \multirow{3}{*}{ Risk Attitude } & $\begin{array}{l}\text { 14. I cannot accept going to travel to the "travel } \\
\text { bubble" destinations with family and friends }\end{array}$ & 0.865 & 0.909 & 0.906 & 0.762 \\
\hline & $\begin{array}{l}\text { 15. I cannot accept that local friends and relatives } \\
\text { travel to the travel bubble destinations }\end{array}$ & 0.928 & & & \\
\hline & $\begin{array}{l}\text { 16. I will not eat with local friends and relatives after } \\
\text { their trip to the travel bubble destination }\end{array}$ & 0.823 & & & \\
\hline \multirow{3}{*}{ Travel Intention } & $\begin{array}{l}\text { 17. I would like to travel to the "travel bubble" } \\
\text { destination for some time in the future }\end{array}$ & 0.902 & 0.909 & 0.910 & 0.771 \\
\hline & $\begin{array}{l}\text { 18. I prefer to travel to the "travel bubble" } \\
\text { destination compared with other forms of tourism }\end{array}$ & 0.825 & & & \\
\hline & $\begin{array}{l}\text { 19. I will recommend the "travel bubble" destination } \\
\text { to relative or friends }\end{array}$ & 0.905 & & & \\
\hline
\end{tabular}


Table 3. Latent Variable Correlation Coefficients.

\begin{tabular}{cccccc}
\hline $\begin{array}{c}\text { Latent } \\
\text { Variable }\end{array}$ & $\begin{array}{c}\text { Number of } \\
\text { Items }\end{array}$ & $\begin{array}{c}\text { Fear of } \\
\text { COVID-19 }\end{array}$ & Travel Anxiety & Risk Attitude & $\begin{array}{c}\text { Travel } \\
\text { Intention }\end{array}$ \\
\hline Fear of & 7 & $0.763 *$ & & & \\
COVID-19 & 6 & 0.402 & $0.810 *$ & & \\
Travel Anxiety & 3 & 0.465 & 0.568 & $0.873 *$ & \\
Risk Attitude & 3 & -0.214 & -0.312 & -0.375 & $0.878^{*}$ \\
Travel Intention & 3 & *
\end{tabular}

* The root square of the average variance extracted for each construct

\subsection{Structural Model Testing}

This study uses structural equation model (SEM) and maximum likelihood to examine the relationship amongst fear of COVID-19, travel anxiety, risk attitude and travel intention towards "travel bubble" destinations. The chi-squared value is 342.795 (99\% significance). Other indicators confirm that the model is acceptable and the data are consistent with the model. The hypothesis paths are hence tested. Table 4 and Figure 1 show the results of the hypothesis testing. The first five hypotheses are significant, namely, $\mathrm{H} 1(t=12.961, p<0.01), \mathrm{H} 2(t=3.448, p<0.01), \mathrm{H} 3(t=4.944, p<0.01)$, $\mathrm{H} 4(t=-3.111, p<0.05)$ and H5 $(t=-1.981, p<0.05)$. However, H6 is non-significant. This result indicates no evidence to suggest a relationship between fear of COVID-19 and travel intention.

Table 4. Direct Path for the Structural Model.

\begin{tabular}{cccccc}
\hline Hypothesis & Path & $\begin{array}{c}\text { Standard } \\
\text { Coefficient }\end{array}$ & $\boldsymbol{t}$-Value & $\boldsymbol{p}$-Value & Decision \\
\hline H1 & Fear of COVID-19 $\rightarrow$ Travel Anxiety & 0.841 & 12.961 & 0.000 & Accept \\
H2 & Fear of COVID-19 $\rightarrow$ Risk Attitude & 0.331 & 3.448 & 0.000 & Accept \\
H3 & Travel Anxiety $\rightarrow$ Risk Attitude & 0.483 & 4.944 & 0.000 & Accept \\
H4 & Travel Anxiety $\rightarrow$ Travel Intention & -0.420 & -3.111 & 0.002 & Accept \\
H5 & Risk Attitude $\rightarrow$ Travel Intention & -0.196 & -1.981 & 0.048 & Accept \\
H6 & Fear of COVID-19 $\rightarrow$ Travel Intention & 0.109 & 0.855 & 0.393 & Reject \\
\hline
\end{tabular}

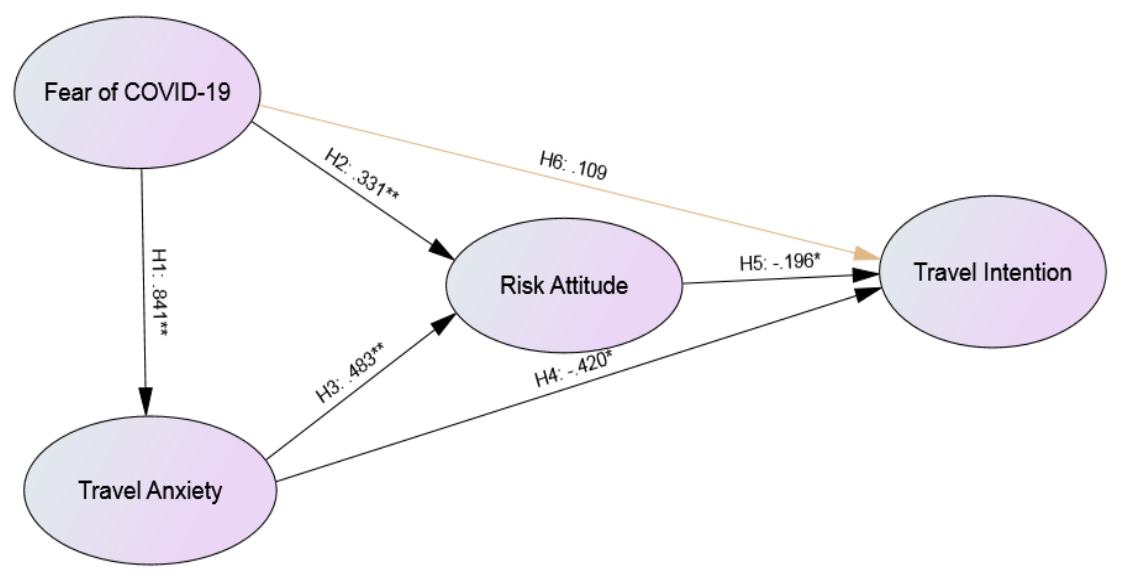

Figure 1. Results of the Hypotheses (Note: ${ }^{* *} p$ value $<0.01{ }^{*} p$ value $<0.05$ ).

The SEM results also show that the indirect effect of fear of COVID-19, connected by travel anxiety and risk attitude, towards travel intention was -0.532 (Table 5). Bootstrapping is employed to investigate the significance of the mediating effect between risk attitude and travel anxiety. After 1000 resamplings, the $95 \%$ confidence interval is $[-0.782,-0.230]$. The interval does not contain zero, which shows that the meditating effect is significant. This result suggests that fear of COVID-19 influenced travel intention through travel anxiety and risk attitude. 
Table 5. Results for Mediation Tests.

\begin{tabular}{cccc}
\hline Causal Relationships & Direct Effect & Indirect Effect & Total Effect \\
\hline Fear of COVID-19 $\rightarrow$ Travel Anxiety & 0.996 & - & 0.996 \\
Fear of COVID-19 $\rightarrow$ Risk Attitude & 0.518 & 0.635 & 1.153 \\
Travel Anxiety $\rightarrow$ Risk Attitude & 0.637 & - & 0.637 \\
Travel Anxiety $\rightarrow$ Travel Intention & -0.486 & -0.109 & -0.595 \\
Risk Attitude $\rightarrow$ Travel Intention & -0.171 & - & -0.171 \\
Fear of COVID-19 $\rightarrow$ Travel Intention & 0.149 & -0.681 & -0.532 \\
\hline
\end{tabular}

\section{Conclusions}

The COVID-19 outbreak created much fear in human society, especially among marginalized and vulnerable people [55]. One of the reasons of such an outbreak is the infection rate of COVID-19. Therefore, many countries utilized different quarantine procedures to reduce the number of imported cases. Under this condition, tourism is severely affected [56]. The results of this study show that people in Hong Kong are increasingly aware of safety in travel. The results revealed important elements that increase travel intention. Although fear of COVID-19 directly affects travel anxiety and risk attitude, travel anxiety and risk attitude have direct negative effects on travel intention. However, no direct relationship exists between fear of COVID-19 and travel intention. In conclusion, Hypotheses 1 to 5 are supported, and Hypothesis 6 is not.

The results confirm the existing literature. Risk and security are some of the key concerns of tourists [49]. When anxiety and risk attitude decrease, travel intention increases. The results support the findings of previous studies $[45,46,49,57]$. This study introduced travel anxiety and risk attitude as mediating variables between fear of COVID-19 and travel intention. While fear of COVID-19 positively affects both travel anxiety and risk attitude ( $\mathrm{H} 1$ and $\mathrm{H} 2)$, anxiety also positively affects risk attitude (H3). The effects of travel anxiety and risk attitude on travel intention are negative and significant (H4 and H5). But the effect of fear of COVID-19 on travel intention is not significant (H6). This means that there is no evidence to suggest that fear of disease reduces people's travel intentions. One explanation of this insignificant result is that COVID-19 is present worldwide; even when people are afraid of COVID-19, the differences between the risks in their hometown and that of a destination may not vary significantly. However, the fear of COVID-19 significantly impacts people's travel anxiety and risk attitude, ultimately making them afraid to travel.

\section{Implications and Future Research}

\subsection{Theoretical Implications}

This study provides some major contributions to tourism literature. First, this study introduces a construct, the fear of COVID-19, into a model. Emotion, which affects people's perceptions and actions, is an important factor that affects human behaviour [58]. This factor is important not only because of its ability to affect human behaviour, but also because of its persistent evolution over time [59]. When an event happens, people will first evaluate it on the basis of their individual experiences, culture and religion. Emotion will then be developed on the basis of this evaluation, and people will respond accordingly. Therefore, each emotion can be explained by using psychological emotion theory [60]. This result can explain how emotion affects people's travel decision from the psychological perspective. Second, this study assesses the indirect impact of the fear of COVID-19 by introducing several mediators, travel anxiety, risk attitudes, and travel intentions. Our results show that fear of COVID-19 affects travel anxiety, risk attitudes, and travel intentions differently. We verified the mediating effects of these three variables. Travel anxiety and risk attitudes are two important mediating variables. This contributes to the tourism literature on tourist behaviours.

Lastly, our results contribute to the destination management literature on factors of outbound tourism. Hong Kong is one of the largest outbound tourist generators in the Asia-Pacific region [61]. Many previous studies of Hong Kong residents' destination choices focus on trip characteristics, 
socio-demographics and travel motivations [62]. None of the previous studies examined "travel bubble" destinations as a destination choice.

\subsection{Managerial Implications}

From the practical point of view, this study provides a good understanding of how fear of COVID-19 affects travel intention via anxiety and risk attitude. This knowledge is crucial for marketing a destination. One of the findings of this study is that the fear of diseases does not deteriorate people's travel intention while anxiety and risk attitude do. Therefore, tourism practitioners, destination marketing organization (DMO)s and governments should focus on reducing people's anxiety and providing a positive risk attitude. Tourism practitioners can increase the appeal of a destination by reducing the perception of risk. In particular, service providers need to have guidelines on cleanliness and services to make sure that guests feel safe. Hotel, airlines and transportation companies should have customized services and stringent safety processes to let tourists feel comfortable within travel. Alternatively, tourism practitioners can explain their contingency plan to tourists more clearly, such that tourists can perceive risks as manageable and under control.

DMOs and the government should use different methods to provide sufficient information to satisfy people's demand for safety, especially for those who have low risk tolerance [46]. Information can be distributed through many resources, such as advertisements on public transportation, social media and health information centres. In addition, these measures to enhance public safety will improve people's perception of safety. Perception of risk is usually affected by local tour operators, guides, news and social media [45]. Although local operators and guides may exaggerate the degree of safety, news and social media may exaggerate the degree of riskiness. Both forms of misguidance may lead to unreasonable concerns. When people are too optimistic, they may become careless, thus increasing the chance of infection. However, when people are too pessimistic, they become anxious. To reduce travel anxiety, tourism practitioners can provide more information about the current risk level of a destination. Alternatively, they can repackage their products to downplay high-risk attractions or activities [49]. Tourists should also be encouraged to obtain information from other resources. Professional and unbiased tour operators can provide accurate information, which reduces the level of misperception and increases the level of security. As a result, the level of anxiety is reduced.

\subsection{Limitations and Future Research}

Since tourism is one of the pillar industries in Hong Kong, therefore, the "travel bubble" is an important tool to recover the economy. The eastern and western countries have different cultures and attitudes to the "travel bubble" destinations. Western people have more carefree attitudes and intentions in travelling during the pandemic, and it is worth comparing the results. A comparative study of the methodologies used in the study in other geographical areas and naturally related to the same theme would have been important. Future research can examine the hypotheses with random samples collected from different countries. This approach would reduce the bias of culture, ethnicity and geography. This study only examined a few constructs, but other constructs such as personality, lifestyle and motivation could be important. Thus, future researchers may consider incorporating other constructs to enrich the model. Finally, given that the COVID-19 outbreak eliminates face-to-face interviews, all surveys were conducted online. Hence, the sample size is limited. Therefore, researchers could increase the sample size to increase the representativeness of the study.

Author Contributions: Conceptualization, J.M.L.; Formal analysis, C.F.L.; Investigation, J.M.L.; Writing-original draft, C.F.L. All authors have read and agreed to the published version of the manuscript.

Funding: This research received no external funding.

Conflicts of Interest: The authors declare no conflict of interest. 


\section{References}

1. UNWTO. International Tourist Numbers Could Fall 608-0\% in 2020, Unwto Reports. 2020. Available online: https://www.unwto.org/news/covid-19-international-tourist-numbers-could-fall-60-80-in-2020 (accessed on 20 July 2020).

2. HKTB. Visitor Arrivals to Hong Kong in July 2020. 2020. Available online: https://partnernet.hktb.com/en/ research_statistics/latest_statistics/index.html (accessed on 31 August 2020).

3. Reuters. Baltics Open Europe's First Pandemic 'Travel Bubble' as Curbs Ease. 2020. Available online: https://www.reuters.com/article/us-health-coronavirus-baltic/baltics-open-europes-firstpandemic-travel-bubble-as-curbs-ease-idUSKBN22Q3KM (accessed on 1 June 2020).

4. Leung, K. Travel Bubbles: Commerce Minister Sounds Cautious Note on Hongkongers' Holiday Plans. SCMP. 2020. Available online: https://www.scmp.com/news/hong-kong/hong-kong-economy/article/3091886/cloudover-hongkongers-summer-holiday-plans-abroad (accessed on 10 July 2020).

5. Locker, M. Five Things to Know About Travel Bubbles. Smithsonian Magazine. 2020. Available online: https://www.smithsonianmag.com/travel/five-things-know-about-travel-bubbles-180974983/ (accessed on 10 July 2020).

6. Yetgin, D.D.D.; Benligiray, S. The effect of economic anxiety and occupational burnout levels of tour guides on their occupational commitment. Asia Pac. J. Tour. Res. 2019, 24, 3333-3347. [CrossRef]

7. Weir, K. Grief and COVID-19: Mourning Our Bygone Lives. American Psychological Association. 1 April 2020. Available online: https://www.apa.org/news/apa/2020/04/grief-covid-19 (accessed on 20 July 2020).

8. Taylor, S. The Psychology of Pandemics: Preparing for the Next Global Outbreak of Infectious Disease; Cambridge Scholars Publishing: Newcastle, UK, 2019.

9. Asmundson, G.J.J.J.; Taylor, S. How health anxiety influences responses to viral outbreaks like COVID-19: What all decision-makers, health authorities, and health care professionals need to know. J. Anxiety Disord. 2020, 71, 102211. [CrossRef]

10. Banerjee, D. The COVID-19 outbreak: Crucial role the psychiatrists can play. Asian J. Psychiatry 2020, 50, 102014. [CrossRef]

11. Smith, A.R.R.; Ebert, E.E.E.; Broman-Fulks, J.J. The relationship between anxiety and risk taking is moderated by ambiguity. Pers. Individ. Differ. 2016, 95, 404. [CrossRef]

12. Ahorsu, D.K.K.; Lin, C.Y.Y.; Imani, V.V.; Saffari, M.M.; Griffiths, M.D.D.; Pakpour, A.H. The fear of COVID-19 scale: Development and initial validation. Int. J. Ment. Heal. Addict. 2020, 27, 19. [CrossRef]

13. Xiang, Y.T.T.; Yang, Y.Y.; Li, W.W.; Zhang, L.L.; Zhang, Q.Q.; Cheung, T.T.; Ng, C.H. Timely mental health care for the 2019 novel coronavirus outbreak is urgently needed. Lancet Psychiatry 2020, 7, 228-229. [CrossRef]

14. Gnoth, J.J.; Zins, A.H.H.; Lengmueller, R.R.; Boshoff, C. Emotions, mood, flow and motivations to travel. J. Travel Tour. Mark. 2000, 9, 233-234. [CrossRef]

15. White, C.C.; Yu, Y.T. Satisfaction emotions and consumer behavioral intentions. J. Serv. Mark. 2005, 19, 4114-4120. [CrossRef]

16. White, C.J. Culture, emotions and behavioural intentions: Implications for tourism research and practice. Curr. Issues Tour. 2005, 8, 5105-5131. [CrossRef]

17. Morris, J.D.D.; Woo, C.C.; Geason, J.A.A.; Kim, J. The power of affect: Predicting intention. J. Advert. Res. 2002, 42, 71-77. [CrossRef]

18. Moyle, B.D.D.; Moyle, C.L.L.; Bec, A.A.; Scott, N. The next frontier in tourism emotion research. Curr. Issues Tour. 2019, 22, 1393-1399. [CrossRef]

19. Gössling, S.S.; Scott, D.D.; Hall, C.M. Pandemics, tourism and global change: A rapid assessment of COVID-19. J. Sustain. Tour. 2020, 1-20. [CrossRef]

20. Hoque, A.A.; Shikha, F.A.A.; Hasanat, M.W.W.; Arif, I.I.; Hamid, A.B.A. The effect of Coronavirus (COVID-19) in the tourism industry in China. Asian J. Multidiscip. Stud. 2020, 3, 525-528.

21. Frijda, N.H. The Emotions. Studies in Emotion and Social Interaction; Cambridge University Press: New York, NY, USA, 1986.

22. Davidson, J.J.; Bondi, L.L.; Smith, M. Emotional Geographies; Ashgate Publishing, Ltd.: Burlington, VT, USA, 2012.

23. Kleinginna, P.R.R.; Kleinginna, A.M. A categorized list of emotion definitions, with suggestions for a consensual definition. Motiv. Emot. 1981, 5, 3453-3479. [CrossRef] 
24. Plutchik, R.; Kellerman, H. (Eds.) Theories of Emotion (Vol. 1); Academic Press: New York, NY, USA, 2013.

25. De Hoog, N.N.; Stroebe, W.W.; de Wit, J.B. The processing of fear-arousing communications: How biased processing leads to persuasion. Soc. Influ. 2008, 3, 84-113. [CrossRef]

26. Mamun, M.A.A.; Griffiths, M.D. First COVID-19 suicide case in Bangladesh due to fear of COVID-19 and xenophobia: Possible suicide prevention strategies. Asian J. Psychiatry 2020, 51, 102073. [CrossRef] [PubMed]

27. Barlow, D.H. Unraveling the mysteries of anxiety and its disorders from the perspective of emotion theory. Am. Psychol. 2000, 55, 1247. [CrossRef]

28. Beck, A.T.T.; Emery, G. Cognitive Therapy of Anxiety and Phobic Disorders; Center for Cognitive Therapy: Guilford, NY, USA, 1979.

29. Rubin, G.J.J.; Wessely, S. Coronavirus: The Psychological Effects of Quarantining a City. The BMJ Opinion. 2020. Available online: https://blogs.bmj.com/bmj/2020/01/24/coronavirus-the-psychological-effects-ofquarantining-a-city/ (accessed on 20 July 2020).

30. Gudykunst, W.B.B.; Hammer, M.R. Strangers and hosts: An uncertainty reduction based theory of intercultural adaptation. Cross-Cultural Adapt. Curr. Approaches 1988, 11, 1061-1139.

31. Dowling, G.R.R.; Staelin, R. A model of perceived risk and intended risk-handling activity. J. Consum. Res. 1994, 21, 119-134. [CrossRef]

32. McIntyre, N.N.; Roggenbuck, J.W. Nature/person transactions during an outdoor adventure experience: A multi-phasic analysis. J. Leis. Res. 1998, 30, 4014-4022. [CrossRef]

33. Hullett, C.R.R.; Witte, K. Predicting intercultural adaptation and isolation: Using the extended parallel process model to test anxiety/uncertainty management theory. Int. J. Intercult. Relations 2001, 25, 125-139. [CrossRef]

34. Satici, B.B.; Gocet-Tekin, E.E.; Deniz, M.E.E.; Satici, S.A. Adaptation of the Fear of COVID-19 Scale: Its association with psychological distress and life satisfaction in Turkey. Int. J. Ment. Heal. Addict. 2020, 8, 1-9. [CrossRef] [PubMed]

35. Kraus, S.J. Attitudes and the prediction of behavior: A meta-analysis of the empirical literature. Pers. Soc. Psychol. Bull. 1995, 21, 58-75. [CrossRef]

36. Hillson, D.D.; Murray-Webster, R. Understanding and Managing Risk Attitude; Gower Publishing, Ltd.: Aldershot, UK, 2007.

37. Maser, B.B.; Weiermair, K. Travel decision-making: From the vantage point of perceived risk and information preferences. J. Travel Tour. Mark. 1998, 7, 107-121. [CrossRef]

38. Kozak, M.M.; Crotts, J.C.C.; Law, R. The impact of the perception of risk on international travellers. Int. J. Tour. Res. 2007, 9, 2332-2342. [CrossRef]

39. Yavas, U. Foreign travel behaviour in a growing vacation market: Implications for tourism marketers. Eur. J. Mark. 1987, 21, 57-69. [CrossRef]

40. Sarin, R.K.K.; Weber, M. Risk-value models. Eur. J. Oper. Res. 1993, 70, 135-149. [CrossRef]

41. Slovic, P. (Ed.) Risk, society, and policy series. In The Perception of Risk; Earthscan Publications: New York, NY, USA, 2000.

42. Caplin, A.A.; Leahy, J. Psychological expected utility theory and anticipatory feelings. Q. J. Econ. 2001, 116, 557-559. [CrossRef]

43. Xie, X.X.; Huang, L.L.; Li, J.J.J.; Zhu, H. Generational Differences in Perceptions of Food Health/Risk and Attitudes toward Organic Food and Game Meat: The Case of the COVID-19 Crisis in China. Int. J. Environ. Res. Public Heal. 2020, 17, 3148.

44. Beerli, A.A.; Martin, J.D. Factors influencing destination image. Ann. Tour. Res. 2004, 31, 6576-6581. [CrossRef]

45. Sönmez, S.F.F.; Graefe, A.R. Influence of terrorism risk on foreign tourism decisions. Ann. Tour. Res. 1998, 25, 1121-1144. [CrossRef]

46. Zhu, H.H.; Deng, F. How to Influence Rural Tourism Intention by Risk Knowledge during COVID-19 Containment in China: Mediating Role of Risk Perception and Attitude. Int. J. Environ. Res. Public Heal. 2020, 17, 3514. [CrossRef] [PubMed]

47. George, R. Tourist's perceptions of safety and security while visiting Cape Town. Tour. Manag. 2003, 24, 5755-5785. [CrossRef]

48. Koo, C.C.; Joun, Y.Y.; Han, H.H.; Chung, N. A structural model for destination travel intention as a media exposure. Int. J. Contemp. Hosp. Manag. 2016. [CrossRef] 
49. Reisinger, Y.Y.; Mavondo, F. Travel anxiety and intentions to travel internationally: Implications of travel risk perception. J. Travel Res. 2005, 43, 2122-2125. [CrossRef]

50. Wachyuni, S.S.S.; Kusumaningrum, D.A. The Effect of COVID-19 Pandemic: How are the Future Tourist Behavior? J. Educ. Soc. Behav. Sci. 2020, 67-76. [CrossRef]

51. Fong, L.H.N.N.; Law, R.R.; Ye, B.H. Outlook of tourism recovery amid an epidemic: Importance of outbreak control by the government. Ann. Tour. Res. 2020, 2020, 102951. [CrossRef]

52. Nunnaly, J. Psychometric Theory; McGraw-Hill: New York, NY, USA, 1978.

53. Fornell, C.C.; Larcker, D.F. Evaluating structural equation models with unobservable variables and measurement error. J. Mark. Res. 1981, 18, 39-50. [CrossRef]

54. Hair, J.J.; Anderson, R.R.; Black, B.B.; Babin, B. Multivariate Data Analysis, 7th ed.; Pearson Education: Essex, UK, 2016.

55. Yang, Y.Y.; Zhang, H.H.; Chen, X. Coronavirus pandemic and tourism: Dynamic stochastic general equilibrium modeling of infectious disease outbreak. Ann. Tour. Res. 2020. [CrossRef] [PubMed]

56. Hamilton-Smith, E. Four kinds of tourism? Ann. Tour. Res. 1987, 14, 3323-3344. [CrossRef]

57. Morakabati, Y.Y.; Fletcher, J.J.; Prideaux, B. Tourism development in a difficult environment: A study of consumer attitudes, travel risk perceptions and the termination of demand. Tour. Econ. 2012, 18, 953-969. [CrossRef]

58. Cherry, K. Overview of the 6 Major Theories of Emotion. 2019. Available online: https://www.verywellmind. com/theories-of-emotion-2795717 (accessed on 20 June 2020).

59. Moors, A. Theories of emotion causation: A review. Cogn. Emot. 2009, 23, 6256-6262. [CrossRef]

60. Mullins, J.K.K.; Sabherwal, R. Gamification: A cognitive-emotional view. J. Bus. Res. 2020, 106, 304-314. [CrossRef]

61. Luo, J.M.M.; Lam, C.F.F.; Qiu, H.H.; Fan, D.X. The Impact of Climate on Outbound Tourism in Hong Kong: Resident's Mode of Transport. J. Mgmt. Sustain. 2015, 5, 31. [CrossRef]

62. Guillet, B.D.D.; Lee, A.A.; Law, R.R.; Leung, R. Factors affecting outbound tourists' destination choice: The case of Hong Kong. J. Travel Tour. Mark. 2011, 28, 5565-5566. [CrossRef]

Publisher's Note: MDPI stays neutral with regard to jurisdictional claims in published maps and institutional affiliations.

(C) 2020 by the authors. Licensee MDPI, Basel, Switzerland. This article is an open access article distributed under the terms and conditions of the Creative Commons Attribution (CC BY) license (http://creativecommons.org/licenses/by/4.0/). 